\title{
LGR5 wt Allele
}

National Cancer Institute

\section{Source}

National Cancer Institute. LGR5 wt Allele. NCI Thesaurus. Code C101485.

Human LGR5 wild-type allele is located within 12q22-q23 and is approximately $147 \mathrm{~kb}$ in length. This allele, which encodes leucine-rich repeat-containing G-protein coupled receptor 5 protein, is involved in signaling. 